\title{
PENERAPAN KRIPTOGRAFI PADA REST API WEB SERVICE STUDI KASUS KAFA PHOTOGRAPHY
}

\author{
${ }^{1}$ Joko Christian Chandra, ${ }^{2}$ Irfan Irmawan \\ ${ }^{1}$ Program Studi Manajemen Informatika, Fakultas Teknologi Informasi, Universitas Budi Luhur \\ ${ }^{2}$ Program Studi Teknik Informatika, Fakultas Teknologi Informasi, Universitas Budi Luhur \\ Jl. Raya Ciledug, Petukangan Utara, Kebayoran Lama, Jakarta Selatan 12260 \\ ${ }^{1}$ joko.christian@budiluhur.ac.id, ${ }^{2}$ irmawanirfan3@gmail.com,
}

\begin{abstract}
.
High business competition forces businesses to adapt to the needs of increasingly complex information systems. One of the market demands is the ease of conducting transactions that are mobile but still integrated with the company's overall information system. This challenge is also faced by a small business Kafa Photography engaged in the field of photography services for public. This business requires a data access system that is secure and supports multiple interfaces. Utilizing REST web service technology that can be used as a communication bridge between different access technologies can help the intended system integration. To improve the security of business process related information, it is necessary to add a cryptographic data mechanism. This research will develop a middleware utilizing the viginere cipher cryptographic method on REST-based web service services for the Kafa Photography business venture. The results of research in the form of web service architecture which are used as connectors between different applications, namely web and mobile that support business processes. To test the functionality and compatibility of the outcome, researcher use the Postman application tool and the prototype of mobile and web applications. The effectiveness and efficiency of derivative applications that use web services to improve services for Kafa Photography customers are not measured in this study.
\end{abstract}

Keywords: cryptography, middleware, rest, viginere cipher, web service

\section{PENDAHULUAN}

Keamanan jaringan komputer merupakan bagian dari sebuah sistem yang sangat penting karena menjaga validitas dan integritas data serta untuk menjamin ketersediaan layanan bagi penggunaannya. Untuk menjaga keamanan dan kerahasiaan data dari ancaman serangan maka diterapkan ilmu kriptografi. Kriptografi merupakan ilmu sekaligus seni untuk menjaga kerahasiaan pesan atau data dengan cara menyamarkan menjadi bentuk yang ter sandi atau berupa simbol-simbol yang tidak mempunyai makna. Dalam kriptografi dikenal dua penyandian yaitu enkripsi dan dekripsi. Teknik ini berguna untuk membuat pesan atau data yang masuk tidak dapat terbaca oleh orang lain. Pentingnya keamanan data sangat dipahami oleh bisnis Kafa Photography yang akan merugikan apabila isi basis data jatuh kepada pihak yang tidak bertanggung jawab. Bisnis ini memerlukan sebuah middleware untuk menghubungkan sistem informasi berbasis mobile dan sistem informasi berbasis web yang sedang dikembangkan. Untuk menjawab kebutuhan tersebut, peneliti akan mengembangkan sebuah middleware berupa web service berbasis Representational State Transfer (REST) dengan memanfaatkan algoritma kriptografi viginere cipher.

Arsitektur ini dapat digunakan oleh beberapa macam jenis client seperti aplikasi mobile (android), dan aplikasi web, yang dapat membantu pelanggan Kafa Photography dalam melakukan layanan jasa fotografi dan juga mempermudah dalam menerima pesanan dari pelanggan.

Permasalahan riset adalah belum adanya sistem middle ware yang dapat digunakan tempat riset untuk mengintegrasikan layanan aplikasi web dan mobile. Pertanyaan riset adalah: "Bagaimana 
melakukan proses perancangan dan pengembangan sistem middleware dengan kriptografi yang menggunakan webservice berbasis REST agar dapat diimplementasikan untuk tempat riset?".

Riset ini sendiri tidak mengembangkan secara eksplisit antarmuka berbasis web dan mobile yang akan memanfaatkan web service tersebut. Analisis proses bisnis, perancangan model database dan antarmuka pengguna juga diluar dari ruang lingkup yang akan dibahas pada tulisan ini.

\section{METODE PENELITIAN}

Metodologi penelitian menggunakan pola System Development Life Cycle dengan pola waterfall, yang membagi proses penelitian menjadi 5 bagian utama:

1. Pengumpulan kebutuhan

2. Analsis

3. Design

4. Implementation

5. Testing

\section{Pengumpulan kebutuhan}

Pengumpulan kebutuhan diawali dengan tinjauan pustaka terkait komponen yang akan digunakan.

\section{Web Service}

Web service merupakan salah satu bentuk sistem perangkat lunak yang didesain untuk mendukung interaksi dari mesin-ke-mesin melalui jaringan internet. Web service ini memiliki interface yang dideskripsikan dalam format yang dapat dibaca oleh mesin. Web service digunakan untuk suatu fasilitas yang disediakan oleh suatu web site untuk menyediakan layanan dalam bentuk informasi kepada sistem yang lainnya, sehingga sistem lain dapat berinteraksi dengan sistem tersebut yang melalui layanan-layanan (service). Web service menyimpan data informasi dalam format standar seperti HTTP,XML, dan JSON [1]. Adapun Arsitektur web service yang di tunjukkan pada Gambar 1. 

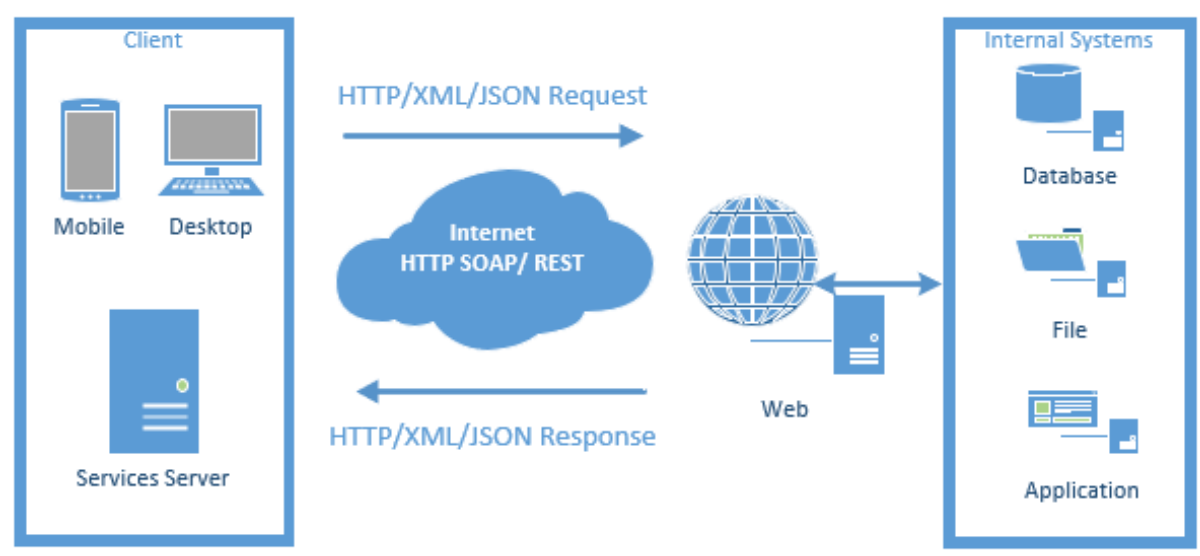

Gambar 1. Arsitektur Web Service

\section{Representational State Transfer (REST)}

REST merupakan salah satu jenis arsitektur web service yang merupakan perbaikan dari SOAP, yaitu versi awal untuk transportasi RPC menggunakan teknologi web, namun tidak benar-benar mengimplementasikan model arsitektur web service [1]. REST menerapkan konsep dengan menggunakan perpindahan antar state. Maksud dari state disini dapat digambarkan misalnya jika browser meminta suatu halaman pada web, maka server akan mengirimkan state halaman web yang sekarang ke browser. Dengan bernavigasi melalui link-link yang disediakan sama halnya mengganti state dari halaman web tersebut. Demikian REST bekerja, dengan bernavigasi yang menggunakan link-link HTTP untuk melakukan aktivitas tertentu. Web service REST pada dasarnya memanfaatkan URL (Uniform Resource Locator) sebagai representasi dari resource web yang ingin digunakan melalui perintah protokol HTTP (GET, POST, PUT dan DELETE). Orientasi pada resource merupakan orientasi yang menyediakan resource-resource sebagai layanannya dan bukan suatu kumpulan-kumpulan dari aktifitas yang mengolah resource itu. Selain itu, karena dengan adanya standar yang masih kurang tidak begitu cocok diterapkan dalam aplikasi yang membutuhkan kerjasama antar aplikasi lain, dimana standar yang baik akan sangat berguna karena berinteraksi dalam satu bahasa yang sama [2]. Adapun Arsitektur REST yang ditunjukkan pada Gambar 2.

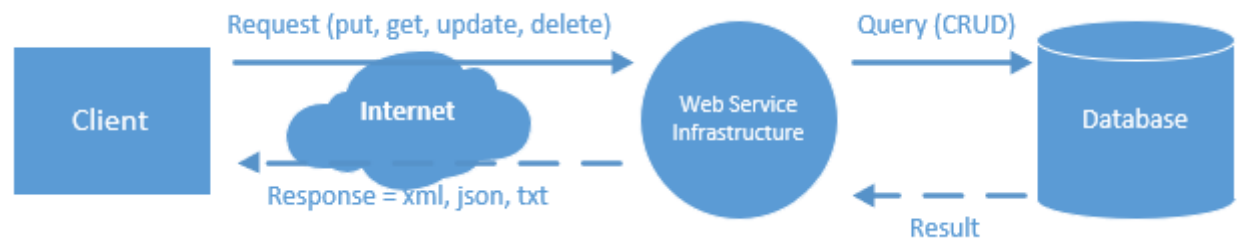

Gambar 2. Arsitektur REST

REST APIs bersifat stateless, berarti panggilan dapat dibuat secara independent, dan setiap panggilan memiliki semua data yang diperlukan untuk proses yang sukses [3]. arsitektur REST ini menentukan sekumpulan prinsip arsitektur yang dapat digunakan untuk merancang web service yang berfokus pada sumber daya sistem. Sumber daya yang dialamatkan dan ditransfer melalui link-link HTTP oleh berbagai macam client yang ditulis dengan bahasa pemrograman yang berbeda. Dengan demikian REST dapat mengoperasikan operasi CRUD (Create, Read, Update, dan Delete) yang dapat dilakukan dengan cara memanfaatkan metode HTTP yang diantaranya POST, GET, PUT dan DELETE. Keuntungan dari pemanfaatan REST adalah tidak perlu mengganti protokol jaringan karena bisa diaplikasikan pada infrastruktur jaringan yang sudah ada [4].Tabel 1 menunjukkan pemetaan operasi CRUD ke dalam permohonan HTTP.

Tabel 1. Pemetaan metode HTTP pada REST 


\begin{tabular}{cccc}
\hline $\begin{array}{c}\text { Operasi } \\
\text { CRUD }\end{array}$ & $\begin{array}{c}\text { HTTP } \\
\text { Method }\end{array}$ & $\begin{array}{c}\text { Format } \\
\text { Application/x } \\
\text { www-form } \\
\text { URL } \\
\text { encoded }\end{array}$ & $\begin{array}{c}\text { HTTP } \\
\text { Status }\end{array}$ \\
\hline Create & POST & $\begin{array}{c}\text { HTTP Form } \\
\text { Encoded }\end{array}$ & $\begin{array}{c}\text { Status 201 } \\
\text { CREATED }\end{array}$ \\
\hline Read & GET & - & $\begin{array}{c}\text { Status 200 } \\
\text { (OK) }\end{array}$ \\
\hline Update & PUT & $\begin{array}{c}\text { HTTP Form } \\
\text { Encoded }\end{array}$ & $\begin{array}{c}\text { Status 200 } \\
(\mathrm{OK})\end{array}$ \\
\hline Delete & DELETE & - & $\begin{array}{c}\text { Status 200 } \\
\text { (OK) }\end{array}$ \\
\hline
\end{tabular}

Format yang digunakan dari Application/xwww-form-URLencoded dengan menerapkan masing-masing metode HTTP yang diantaranya GET dan DELETE berbeda dengan POST dan PUT, hal tersebut dikarenakan cara parsing data yang berbeda.

Metode pada parsing data GET dan DELETE dimulai melalui URL, sedangkan untuk metode POST dan PUT parsing data tersebut melalui payload HTTP dengan memanfaatkan media type 'Application/xwww-form-URLencoded'. Berikut adalah kode status

HTTP Response Server terhadap aksi yang dilakukan oleh Client, diantaranya :

1) Kode dengan status 201: Request ini telah terpenuhi sehingga menghasilkan sumber daya yang baru Create.

2) Kode dengan status 200: Response ini standar untuk Request HTTP dari client yang dinyatakan dengan sukses oleh server. Untuk response yang sebenarnya akan tergantung pada metode Request yang akan digunakan.[5]

\section{Aplication Programming Interface (API)}

Aplication Programming Interface (API) merupakan software interface yang terdiri dari kumpulan intruksi (interface, fungsi, kelas, struktur dan sebagainya) yang disimpan dalam bentuk library. API dapat dikatakan sebagai penghubung suatu software dengan software lainnya yang memungkinkan seorang programmer menggunakan sistem function. Proses ini dikelola dengan melalui sistem operasi. Keunggulan dari API ini adalah memungkinkan suatu software dengan software lainnya dapat saling berhubungan dan berinteraksi.

Penjelasan tersebut dapat dicontohkan dengan analogi untuk membangun suatu rumah. Dengan menyewa kontraktor yang dapat menangani bagian-bagian yang berbeda. Pada pemilik rumah ini dapat memberikan tugas yang perlu dilakukan oleh

kontraktor tanpa harus mengetahui bagaimana cara kontraktor menyelesaikan pekerjaan tersebut. Dari analogi tersebut, rumah yang merupakan software yang akan dibuatnya, dan kontraktor merupakan API yang mengerjakan bagian-bagian tertentu dari software tersebut, serta tanpa harus diketahui bagaimana prosedur dalam melakukan pekerjaan tersebut [6] Adapun Arsitektur API yang ditunjukkan pada gambar 3. 


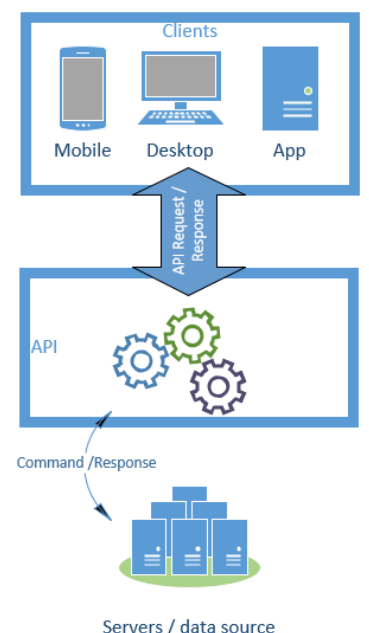

Gambar 3. Arsitektur API

\section{Vigenere Cipher}

Vigenere cipher merupakan salah satu Algoritma kriptografi klasik yang diperkenalkan pada abad ke 16 atau kira-kira pada tahun 1986. Algoritma kriptografi ini sudah dipublikasikan oleh seorang diplomat dan juga kriptologis yang berasal dari negara Perancis, yang bernama Blaise de Vigenère, namun sebenarnya algoritma tersebut telah digambarkan sebelumnya pada buku La Cifra del Sig. Giovan Batista Belaso, sebuah buku yang ditulis oleh Giovan Batista Belaso, pada tahun 1553. Cara kerja dari algoritma vigenere cipher ini mirip dengan algoritma caesar cipher, yaitu dengan mengenkripsi plaintext pada pesan dengan cara menggeser huruf pada pesan tersebut sejauh nilai kunci pada deret huruf alphabet [7]. Vigenere cipher adalah salah satu Algoritma kriptografi klasik yang menggunakan metode substitusi abjad majemuk. Substitusi abjad-majemuk mengenkripsi setiap huruf yang ada dengan menggunakan kunci yang berbeda. Sedangkan pada algoritma caesar cipher yang menerapkan metode substitusi abjad-tunggal dengan semua huruf disuatu pesan yang dienkripsi menggunakan kunci yang sama.

Model matematika dari enkripsi pada Algoritme vigenere cipher ini adalah seperti berikut :

$$
\mathrm{C} i=\mathrm{Ek}(\mathrm{M} i)=(\mathrm{M} i+\mathrm{K} i) \bmod 26
$$

Dan model matematika untuk deskripsinya adalah :

$$
\mathrm{M} i=\mathrm{Dk}(\mathrm{C} i)=(\mathrm{C} i-\mathrm{K} i) \bmod 26
$$

Dengan $\mathrm{C}$ memodelkan ciphertext, $\mathrm{M}$ memodelkan plaintext, dan $\mathrm{K}$ memodelkan kunci.

Kunci pada kriptografi Vigenere adalah sebuah kata bukan sebuah huruf. Kata kunci ini akan dibuat berulang sepanjang plaintext, sehingga jumlah huruf pada kunci akan sama dengan jumlah huruf pada plaintext [8]. Adapun contoh dari penerapan algoritma vigenere cipher ini yang memiliki sebuah plaintext dan akan dienkripsi :

\section{Plaintext : PENELITIAN KOMPUTER \\ Kunci : JOKOIRFAN}

Maka plaintext tersebut akan dienkripsi dengan cara :

Plaintext : PENELITIAN KOMPUTER

Kunci : JOKOIRFANJ OKOIRFAN 


\section{Ciphertext : YSXSTZYINW YYAXLYEE}

Pada huruf kunci tersebut akan dikonversi menjadi sebuah nilai, yang misalnya $\mathrm{A}=0, \mathrm{~B}=1$, sampai dengan $Z=25$. Setelah itu prosesnya sama seperti pada algortima caesar cipher yang dimana setiap huruf pada plaintext tersebut akan digeser sejauh nilai kunci yang posisinya bersesuaian. Pergeseran pada huruf-huruf tersebut bisa dipetakan dalam bentuk tabel 26x26 yang memetakan antara huruf pada plaintext dengan huruf pada kunci. Adapun tabel pemetaan algoritma vigenere cipher yang diperlihatkan pada Gambar 4.

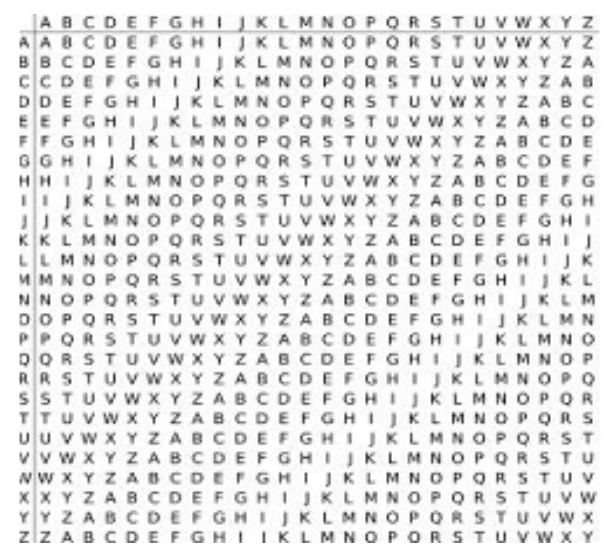

Gambar 4. Tabula Recta Viginere Cipher (https://crypto.interactive-maths.com/vigenegravere-cipher.html, Mei 2019)

Selain menggunakan algoritma vigenere cipher bujur sangkar atau tabel pemetaan, vigenere cipher ini dapat dilakukan dengan cara menjumlahkan plaintext dengan kunci yang kemudian di modulo 26. Dengan asumsi $\mathrm{a}=0, \mathrm{~b}=1, \mathrm{c}=2, \ldots \ldots, \mathrm{z}=25$ [9].

\section{JSON Web Token (JWT)}

JSON Web Token (JWT) merupakan standar format untuk mengamankan informasi pribadi menjadi sebuah klaim yang akan di encode ke dalam bentuk JSON dan menjadi Payload dari JSON Web Signature (JWS). Klaim ini yang akan dapat dilindungi dengan tanda tangan digital seperti Message Authentication Code (MAC) atau dienkripsi [10]. JWT terdiri dari beberapa bagian, bagian pertama adalah header yang ter-encode base64url dan dipisahkan dengan karakter koma (,) [11].

\section{Analisis Data}

Berdasarkan tinjuauan pustaka, hasil wawancara dan studi dokumentasi, peneliti melakukan proses penentuan komponen yang akan digunakan dalam penelitian, dan menentukan batasan masalah.

\section{Design Sistem}

Proses ini mencakup desain arsitektur sistem berbasis web service Representational StateTransfer (REST) yang akan dikembangkan.

\section{Implementation}

Implementasi merupakan proses pengembangan code yang dilandasi dari hasil analisis dan desain 


\section{Testing/Pengujian}

Testing ditujukan untuk menguji operasionalitas dari hasil penelitian yang dihasilkan.

\section{HASIL DAN PEMBAHASAN}

\section{Rancangan Arsitektur Program}

Rancangan arsitektur pada layanan web service ini terdapat adanya sebuah proses enkripsi dan dekripsi data antara client dan server. Sebelum mengirimkan sebuah request ke server, client harus melakukan autentikasi yang berupa email dan password. Kemudian data yang dikirimkan dari client akan diterima oleh server, dan server akan melakukan proses enkripsi data yang telah diterima serta menyimpannya di database server. Ketika client mengirimkan sebuah request ke server, server akan melakukan dan mengirimkan response serta mendekripsikan data tersebut sebelum dikirim kembali menuju ke client. Adapun arsitektur program seperti yang ditunjukkan pada Gambar 5.

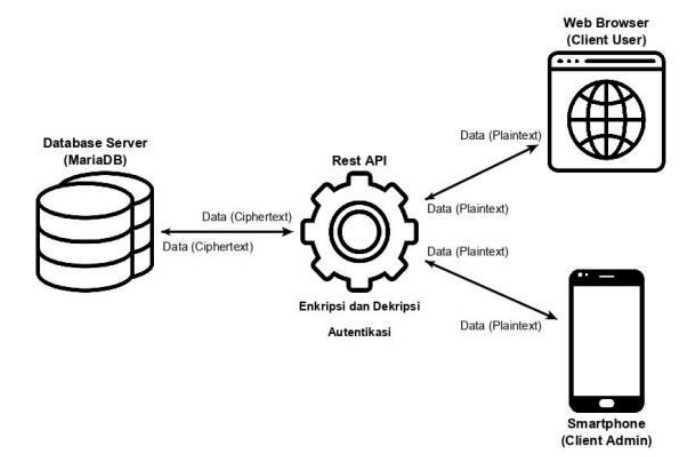

Gambar 5.Arsitektur sistem yang dikembangkan

\section{Rancangan Layanan Web Service}

Berikut ini merupakan rancangan web service yang menjelaskan tentang URL API (Uniform Resource Locator Application Programming Interface) atau biasa disebut dengan endpoint dari server Kafa Photography. Rancangan web service ini terbagi menjadi 2 kategori endpoint, yaitu sisi user (pelanggan) seperti pada Tabel 2 dan sisi admin. Detil bisa dilihat seperti pada Tabel 3.

Tabel 2. Rancangan Web Service Endpoint User

\begin{tabular}{|c|c|c|c|c|}
\hline $\begin{array}{c}\text { Nama } \\
\text { Layana } \\
\text { Daftar }\end{array}$ & $\begin{array}{c}\text { Meto } \\
\text { de }\end{array}$ & $\begin{array}{c}\text { Endpoi } \\
\text { nt }\end{array}$ & $\begin{array}{c}\text { Par } \\
\text { am } \\
\text { eter }\end{array}$ & Output \\
\hline POST & $\begin{array}{c}\text { User } \\
\text { (Pelang } \\
\text { gan) } \\
\text { (daftar) }\end{array}$ & $\begin{array}{c}\text { Success, } \\
\text { message }\end{array}$ \\
\hline $\begin{array}{c}\text { Pesan } \\
\text { Lelang } \\
\text { gan) } \\
\text { n Jasa }\end{array}$ & POST & $\begin{array}{c}\text { POST } \\
\text { (login) }\end{array}$ & $\begin{array}{c}\text { User } \\
\text { (Pelang } \\
\text { gan) }\end{array}$ & $\begin{array}{c}\text { token, } \\
\text { success, } \\
\text { message }\end{array}$ \\
\hline
\end{tabular}




\begin{tabular}{|c|c|c|c|c|}
\hline & & $\begin{array}{c}\text { (pesana } \\
\mathrm{n})\end{array}$ & & \\
\hline $\begin{array}{c}\text { Confir } \\
\text { m } \\
\text { Pembay } \\
\text { aran }\end{array}$ & POST & $\begin{array}{c}\text { User } \\
\text { (Pelang } \\
\text { gan) } \\
\text { (pemba } \\
\text { yaran) }\end{array}$ & & $\begin{array}{l}\text { success, } \\
\text { message }\end{array}$ \\
\hline $\begin{array}{c}\text { List } \\
\text { Pesanan }\end{array}$ & GET & $\begin{array}{c}\text { User } \\
\text { (Pelang } \\
\text { gan) } \\
\text { (pesana } \\
\text { n) } \\
\end{array}$ & $\begin{array}{l}\mathrm{kd}_{-} \\
\text {pes } \\
\text { an }\end{array}$ & $\begin{array}{l}\text { pesanan, } \\
\text { success, } \\
\text { message }\end{array}$ \\
\hline $\begin{array}{c}\text { List } \\
\text { Status } \\
\text { Pembay } \\
\text { aran }\end{array}$ & GET & $\begin{array}{c}\text { User } \\
\text { (Pelang } \\
\text { gan) } \\
\text { (pemba } \\
\text { yaran) }\end{array}$ & $\begin{array}{l}\mathrm{kd}_{-} \\
\text {bay } \\
\text { ar }\end{array}$ & $\begin{array}{c}\text { pembayara } \\
\text { n, success, } \\
\text { message }\end{array}$ \\
\hline Profile & GET & $\begin{array}{c}\text { User } \\
\text { (Pelang } \\
\text { gan) } \\
\text { (pelang } \\
\text { gan) }\end{array}$ & $\begin{array}{l}\mathrm{kd}_{-} \\
\text {pela } \\
\text { ngg } \\
\text { an }\end{array}$ & $\begin{array}{l}\text { pelanggan, } \\
\text { success, } \\
\text { message }\end{array}$ \\
\hline
\end{tabular}

Tabel 3.Rancangan Web Service Endpoint Adm

\begin{tabular}{|c|c|c|c|c|}
\hline $\begin{array}{c}\text { Nama } \\
\text { Layan } \\
\text { an }\end{array}$ & $\begin{array}{c}\text { Meto } \\
\text { de }\end{array}$ & $\begin{array}{c}\text { Endpoi } \\
\text { nt }\end{array}$ & $\begin{array}{c}\text { Par } \\
\text { am } \\
\text { eter }\end{array}$ & Output \\
\hline Login & POST & $\begin{array}{c}\text { Admin } \\
\text { (login) }\end{array}$ & $\begin{array}{c}\text { token, } \\
\text { success, } \\
\text { message }\end{array}$ \\
\hline Daftar & POST & $\begin{array}{c}\text { Admin } \\
\text { (daftar) }\end{array}$ & $\begin{array}{c}\text { success, } \\
\text { message }\end{array}$ \\
\hline $\begin{array}{c}\text { List } \\
\text { Daftar } \\
\text { Pesana } \\
\text { n }\end{array}$ & GET & $\begin{array}{c}\text { Pelang } \\
\text { gan } \\
\text { (pesana } \\
\text { n) }\end{array}$ & $\begin{array}{c}\text { stat } \\
\text { us_ } \\
\text { pes } \\
\text { an }\end{array}$ & $\begin{array}{c}\text { pesanan, } \\
\text { success, } \\
\text { message }\end{array}$ \\
\hline $\begin{array}{c}\text { List } \\
\text { Daftar } \\
\text { Pemba } \\
\text { yaran }\end{array}$ & GET & $\begin{array}{c}\text { Pelang } \\
\text { gan } \\
\text { (pemba } \\
\text { yaran) }\end{array}$ & $\begin{array}{c}\text { stat } \\
\text { us_ } \\
\text { pes } \\
\text { an }\end{array}$ & $\begin{array}{c}\text { pembaya } \\
\text { ran, } \\
\text { success, } \\
\text { message }\end{array}$ \\
\hline $\begin{array}{c}\text { List } \\
\text { Daftar } \\
\text { Pelang } \\
\text { gan }\end{array}$ & GET & $\begin{array}{c}\text { Pelang } \\
\text { gan } \\
\text { (pelang } \\
\text { gan) }\end{array}$ & $\begin{array}{c}\text { kd_ } \\
\text { pela } \\
\text { ngg } \\
\text { an }\end{array}$ & $\begin{array}{c}\text { pelangga } \\
\text { nuccess, } \\
\text { message }\end{array}$ \\
\hline $\begin{array}{c}\text { Edit } \\
\text { Pesana } \\
n\end{array}$ & POST & $\begin{array}{c}\text { Admin } \\
\text { (editpes } \\
\text { anan) }\end{array}$ & $\begin{array}{c}\text { Admin } \\
\text { (editpe } \\
\text { mbayar } \\
\text { an) }\end{array}$ & $\begin{array}{c}\text { success, } \\
\text { message }\end{array}$ \\
\hline $\begin{array}{c}\text { Edit } \\
\text { Pemba } \\
\text { yaran }\end{array}$ & POST & $\begin{array}{c}\text { success, } \\
\text { message }\end{array}$ \\
\hline
\end{tabular}




\section{Flowchart Algoritma Vigenere Cipher}

Berikut ini adalah flowchart dan algoritma vigenere cipher yang merupakan proses pada web service (API) terlihat pada gambar 6, dan dekripsi data terlihat pada gambar 7.

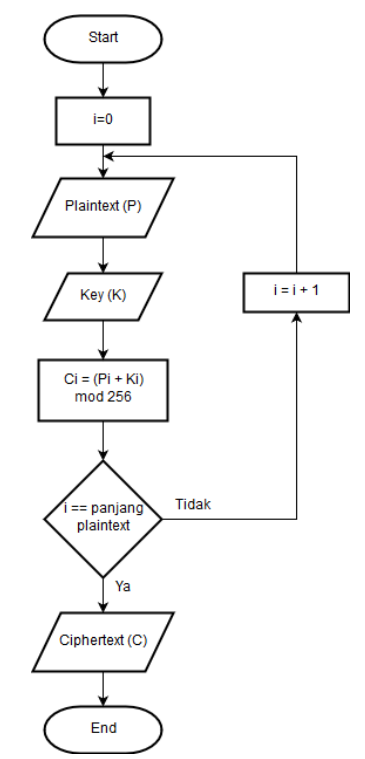

Gambar 6. Flowchart Viginere Cipher

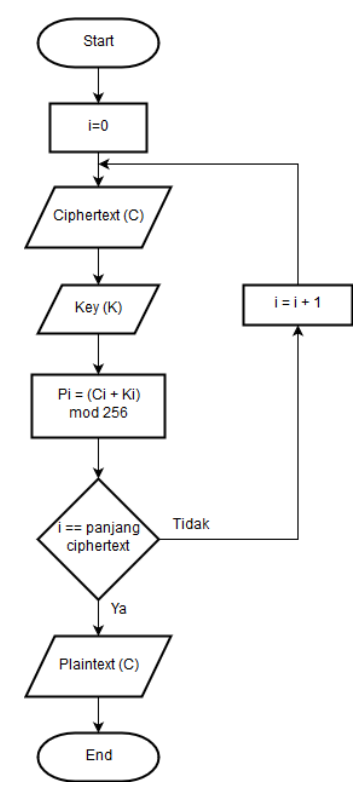

Gambar 7.Flowchart Dekripsi Viginere Cipher

\section{TESTING /UJI COBA}

Uji coba dilakukan menggunakan aplikasi berbasis mobile dan web (keduanya diluar dari batasan masalah tulisan ini) dan dengan output dari tool postman. Karena keterbatasan tempat, hanya beberapa fitur yang ditunjukkan pada tulisan ini. 


\section{Login}

Tampilan login ini merupakanhalaman otentikasi untuk user yang sudah melakukan pendaftaran sebelumnya, terlihat pada gambar 8, sendangkan pada gambar 9 adalah antar muka aplikasi mobile dan gambar 10 menunjukkan fungsionalitas web service untuk proses tersebut.

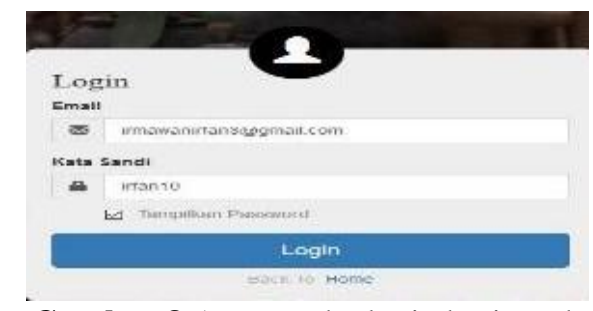

Gambar 8. Antar muka login basis web

\section{KAFA}

iffan123@gmail.com

$\cdots$

Gambar 9.Antar muka login basis mobile

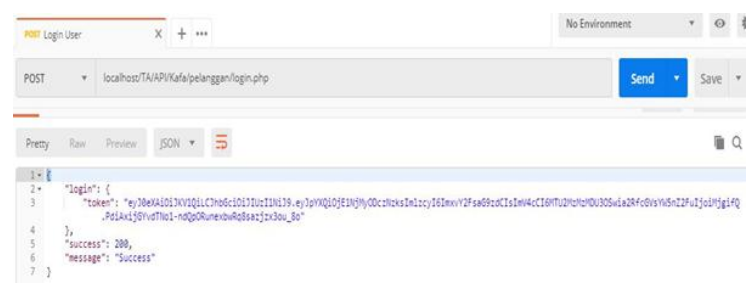

Gambar 10.Output proses REST untuk login

\section{$\underline{\text { Pesanan }}$}

Proses pemesanan jasa oleh user berbasis web yang terlihat pada Gambar 11, sedangkan pada Gambar 12 adalah antar muka aplikasi mobile untuk edit data pesanan dan Gambar 13 menunjukkan output pesan REST dari web service untuk proses edit detil pesanan tersebut.

Sebagian dari data pesanan mengalami proses enkripsi sebelum disimpan ke dalam database dan proses dekripsi saat dibaca dari database. 


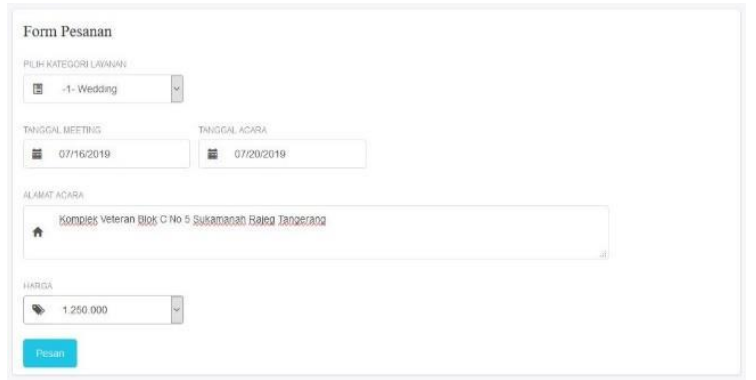

Gambar 11. Antar muka web proses pesan jasa

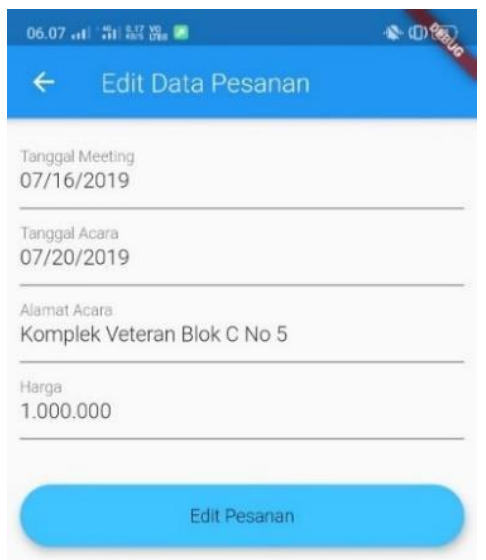

Gambar 12. Antar muka mobile edit data pesanan

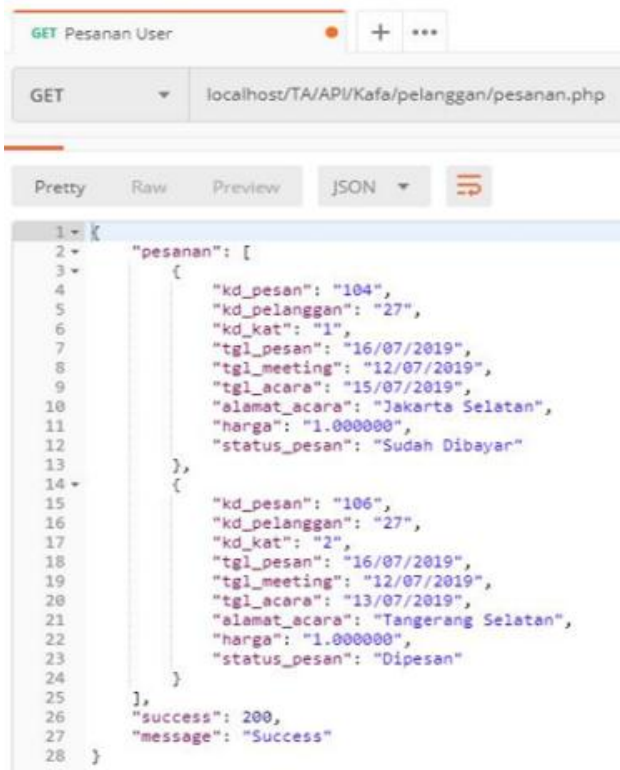

Gambar 13. Output REST message untuk edit pesanan 


\section{$\underline{\text { Pembayaran }}$}

Proses pembayaran juga menggunakan proses enkripsi dan dekripsi. Gambar 14 menunjukkan tampilan layer dari sisi web, Gambar 15 menunjukkan tampilan layar dari sisi mobile untuk edit data pembayaran (admin), dan Gambar 16 menunjukkan output REST message untuk list daftar pembayaran pelanggan.

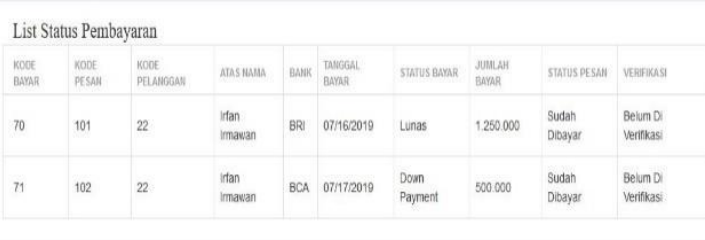

Gambar 14. Antar muka web list pembayaran

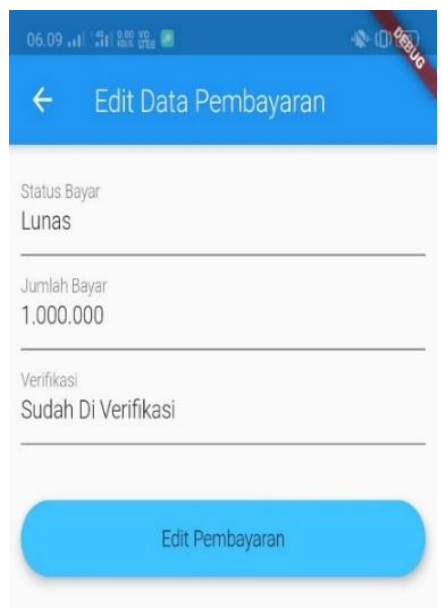

Gambar 15.Antar muka mobile edit pembayaran

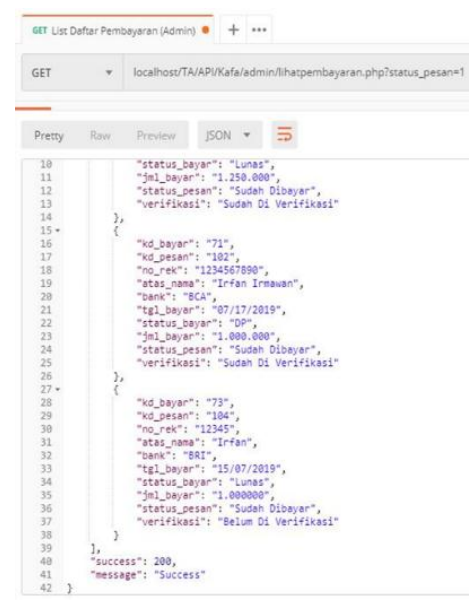

Gambar 16. Output REST message untuk list daftar pembayaran pelanggan.

\section{Analisis data terkriptografi}

Data yang disimpan pada database telah melalui proses kriptografi, sehingga yang disimpan adalah data cipher yang bisa terlihat pada Gambar 17 dan Gambar 18. 


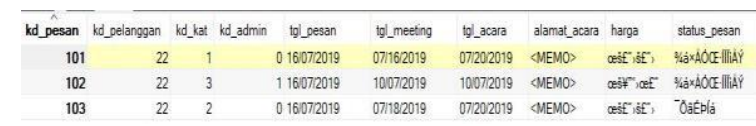

Gambar 17.Potongan data pesanan terenkripsi

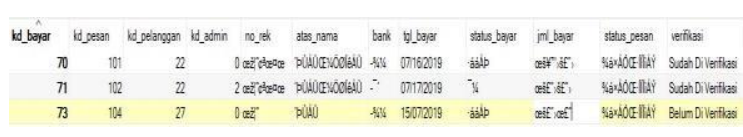

Gambar 18.Potongan data pembayaran terenkripsi

Penelitian ini tidak secara eksplisit melakukan perbandingan dengan algoritma kriptografi lain seperti AES, tetapi berdasarkan karakteristik umur dan kompleksitas operasi, algoritma viginere memberikan keamanan tambahan jika isi database berhasil diambil pihak yang tidak berwenang. Algoritma Viginere ini masih rentan dengan serangan Kasiski, Friedman, Cryptanalysis, frequency analysis, pattern prediction dan brute force [12].

\section{KESIMPULAN}

Setelah melakukan tahap pengumpulan kebutuhan, analisis, perancangan, pengembangan, dan serangkaian uji coba, maka dapat diambil kesimpulan berikut :

1. Metodologi waterfall berhasil diimplementasikan dalam proses pengembangan sistem middleware.

2. Hasil dari pengembangan, berupa sistem middleware berbasis web service dengan REST yang menyimpan data lebih aman karena menggunakan kriptografi viginere

3. Metode REST yang digunakan dalam membuat sebuah web service ini dapat diakses oleh teknologi antar muka yang berbeda seperti aplikasi android dan web, walaupun berbeda bahasa pemrograman dan platform.

Berikut adalah beberapa saran yang dapat dilaksanakan oleh penelitian pengembangan:

1. Penambahan layanan web service end point, karena beberapa proses seperti pembatalan pesanan belum terakomodir.

2. Penggunaan algoritma kriptografi yang lebih kompleks seperti enhanced viginere cipher dan melakukan validase dengan analisis keamanan dan performansi.

\section{DAFTAR PUSTAKA}

[1] S. Vinoski, "RPC and REST: Dilemma, Disruption, and Displacement," IEEE Internet Comput., vol. 12, no. 5, pp. 92-95, Sep. 2008.

[2] S. Sibagariang, "WEB SERVICE REST PADA PERPUSTAKAAN BERBASIS ANDROID," Maharjana Inf., vol. 1, no. 2, pp. 8-11, 2016.

[3] M. Stowe, Undisturbed REST, First. San Francisco, 2015.

[4] F. W. Sari and A. Triwinarko, "Pemanfaatan Kriptografi pada RESTFul Web Service," Integrasi, vol. 7, no. 1, pp. 77-81, 2015.

[5] P. F. Tanaem, D. Manongga, and A. Iriani, "RESTFul Web Service Untuk Sistem Pencatatan Transaksi Studi Kasus PT. XYZ," J. Tek. Inform. dan Sist. Inf., vol. 2, no. 1, pp. 1-10, 2016. 
[6] M. A. Arianto, S. Munir, and K. Khotimah, "ANALISIS DAN PERANCANGAN REPRESENTATIONAL STATE TRANSFER (REST) WEB SERVICE SISTEM INFORMASI AKADEMIK STT TERPADU NURUL FIKRI MENGGUNAKAN YII FRAMEWORK," Teknol. Terpadu, vol. 2, no. 2, 2016.

[7] Efrandi, Asnawati, and Yupiyanti, "APLIKASI KRIPTOGRAFI PESAN MENGGUNAKAN ALGORITMA VIGENERE CIPHER,” Media Infotama, vol. 10, no. 2, pp. 120-128, 2014.

[8] A. Hallim, I. U. Nadhori, and Setiawardhana, "PEMBUATAN PERANGKAT LUNAK MEDIA PEMBELAJARAN KRIPTOGRAFI KLASIK," Semin. Proy. Akhir PENS-ITS $2010,2010$.

[9] M. D. Irawan, "IMPLEMENTASI KRIPTOGRAFI VIGENERE CIPHER DENGAN PHP," Teknol. Inf., vol. 1, no. 1, pp. 11-21, 2017.

[10] A. W. P. Putra, A. Bhawiyuga, and M. Data, "Implementasi Autentikasi JSON Web Token (JWT) Sebagai Mekanisme Autentikasi ProtokolMQTTPada Perangkat NodeMCU," Pengemb. Teknol. Inf. dan Ilmu Komput., vol. 2, no. 2, pp. 584-593, 2018.

[11] M. Jones, J. Bradley, and N. Sakimura, “JSON Web Token (JWT),” May 2015.

[12] Soofi, Aizen Amin, Riaz Irfan, Rasheed Umair, "An Enhanced Viginere Cipher For Data Security," Intl Journal of Scientific \& Technology Research., vol 5, Issue 3, pp. 141-145, 2016. 